
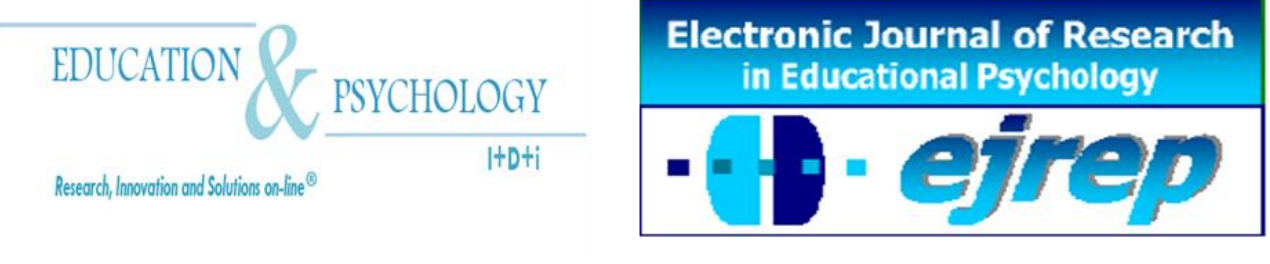

Editorial EOS

\title{
Marital Relationship in Greek Families Raising a Child with a Severe Disability
}

\begin{abstract}
Assimina Tsibidaki
Lecturer of Special Education, Department of Primary Education, University of the Aegean, Rhodes
\end{abstract}

\section{Greece}

Correspondence: Assimina Tsibidaki. 1, Dimokratias str, 85100 Rhodes. Greece.E-mail: tsimpidaki@rhodes.aegean.gr

(C) Education \& Psychology I+D+i and Editorial EOS (Spain) 


\section{Abstract}

Introduction. The target of the study is to examine important aspects of the marital relationship: marital satisfaction, spouse's representation of the marital relationship, roles and boundaries in families raising a child with a severe disability. Also, this study compares families with a child with a severe disability to those with children without disability on the same characteristics.

Method. The sample consists of 120 participants from nuclear families (30 couples with a child with a severe disability and 30 couples with children without disability) who were middle socio-economic class and permanent residents of the island of Rhodes, Greece. This study constitutes a qualitative survey with quantitative comparative elements. Data were collected using the Marital Happiness Scale and semi-structured interviews.

Results. The findings suggest that there is no statistically significant difference between groups in their marital relationship; however, marriage, in the couples with a child with disability, is largely determined by the child's needs. Although mothers of children with a severe disability undertake most child-related responsibilities, couples seem to safeguard their equilibrium by undertaking highly complementary roles.

Conclusion. There are more similarities than differences between couples raising children with or without disability regarding marital satisfaction, role assignment, representation of the marital relationship and boundaries. Future research efforts should be directed to the area of marital relationship aiming family practitioners, clinicians and educators to include both spouses in the evaluation and treatment of the child with a severe disability and to incorporate families into child's care and education.

Key words: marital relationship, child with a severe disability, marital satisfaction, roles, boundaries, Greek families 


\section{Relación Marital en Familias Griegas que Educan a Hijos con Discapacidad Severa}

\section{Resumen}

Introducción. El objetivo del estudio fue examinar los aspectos importantes de la relación marital: satisfacción marital, la representación del cónyuge de la relación marital, roles y límites en las familias con un niño con una discapacidad grave. Además, este estudio compara las familias con un niño con una discapacidad grave a los que tienen hijos sin discapacidad, con las mismas características.

Método. La muestra se compone de 120 participantes provenientes de familias nucleares (30 parejas con un niño con una discapacidad severa y 30 parejas con niños sin discapacidad) de una clase socio-económica media y con residencia permanente en la isla de Rodas (Grecia). Este trabajo constituye una investigación cualitativa con elementos cuantitativos comparativos. Los datos fueron recolectados a través de la Escala de Felicidad Marital y entrevistas semi-estructuradas.

Resultados. Los resultados sugieren que no hay diferencias estadísticamente significativas entre los grupos en su relación marital, sin embargo, el matrimonio, en las parejas con un niño con discapacidad está, en gran parte, determinada por las necesidades del niño. Aunque las madres de niños con discapacidad severa realizan la mayoría de las responsabilidades relacionadas con los niños, las parejas parecen salvaguardar su equilibrio mediante la realización de funciones altamente complementarias.

Conclusión. Hay más similitudes que diferencias entre las parejas que crían niños con o sin discapacidad respecto a la satisfacción marital, asignación de funciones, la representación de la relación marital y límites. Los futuros esfuerzos de investigación deben dirigirse al estudio de la relación marital con el objetivo de la familia, los profesionales médicos y los educadores para incluir a los cónyuges en la evaluación y tratamiento del niño con una discapacidad grave, para incorporar a las familias en la atención del niño y la educación.

Palabras clave: la relación marital, niño con una discapacidad severa, la satisfacción marital, los roles, las fronteras, las familias griegas 


\section{Introduction}

\section{Importance of the marital relationship}

Research has emphasized the benefits of a marital relationship (Stevens \& Westerhof, 2006). People who are married, compared to the unmarried, tend to be happier and are also less prone to loneliness, early mortality, and suicide (Stack \& Eshleman, 1998 as cited in Stevens \& Westerhof, 2006). Whereas the importance of the marital relationship is generally acknowledged, this conclusion is drawn primarily from studies on marriage focusing on the consequences of relationship status and well-being (Kamp-Dush \& Amoto, 2005; Williams, 2003). Despite this consistent research, however to generalize on the marital relationship of families raising a child with a severe disability could be misleading.

Quality of the marital relationship in parents of children with a disability has been the focus of numerous research studies. Many of these studies examined the impact of having a son or a daughter with a disability on the marital relationship (Hartley et. al., 2011). Some studies have indicated that there is no difference on the quality of marital relationship between couples with a child with a disability and couples of children without a disability (Floyd \& Zmich, 1991; Holmbeck et. al., 1997; Patterson, 1991), whereas other studies have suggested an adverse effect of having a child with disability (Florian \& Findler, 2001).

\section{The influence of a child with a severe disability on the marital relationship}

Research focusing on the influence a child with disability has on the marital relationship is contradictory (Dale, 1996; Seligman \& Darling, 2007). Family functions are a complex system of variables requiring repeated research in order to investigate the interaction of many factors [e.g., the psychosocial typology of illness/disability, the family life cycle, family members' personality, other bio-psychosocial systems (Rolland, 1989), and the family's cultural context].

Initially, researchers' working hypothesis was that the presence of a child with disability would have destructive consequences on the marriage. Therefore, they paid particular attention to marital problems assuming that they are associated with the presence of the disability. Gabel, McDowell \& Coreto (1983) in their review of research relating to marital relationship suggest that there are more frequent conflicts, dissatisfaction with the spouse, sexual difficulties, temporary separations and divorce in families with infants with disability. It has 
also been suggested that the existence of a child with a disability in the family disturbs marital harmony (Pahl \& Quine, 1985). Other studies have reported different disability effects across different family subsystems, with the marital subsystem appearing to be especially at risk. For example, Dashiff (1993 as cited in Knafl \& Gilliss, 2002) found that parents reported an increase in family closeness but a decrease in couple closeness as a result of their child's diabetes.

Research data suggest that the presence of a child with disability does not always have a destructive effect on the marital relationship (Seligman \& Darling, 2007). It has even been suggested that some marriages improve after their child is diagnosed as having a disability (Schwab, 1989). The explanation of this finding is that the process of care as well as the confrontation of the existing problem brings spouses emotionally closer. Singer \& Farkas (1989) in a study of the impact of infant disability on maternal stress perceptions found that $85 \%$ of their respondents reported that despite problems the family experienced as a result of the disability, spouses were closer because of their shared experience.

Research findings also suggest that the frequency of marital problems in families of children with disability is not higher compared to families of children without disability (Patterson, 1991). Furthermore, it has been suggested (Callias, 1989), that in families with a greater frequency of marital dysfunction it is not clear whether this is due to stress imposed by the upbringing of the child with disability or to the quality of the marital relationship prior to the birth of the child.

In an unstable marital relationship, the stress of dealing with a child's disability can cause the family system to collapse; on the other hand, in a relationship that is strong and relatively non-stressed, a child's disability may develop increased closeness and strength in the parent's marriage. While there is a general impression that parents who have a child with disability are more likely to split up than parents of children without disability, there has been limited research in this area and it is inconclusive (Havens, 2005).

\section{Culture, Marriage and Children with Disability}

It must be mentioned that the cultural context plays a crucial role on the institution of marriage. In the Greek culture, for example, this institution possesses an important place in the community. A lot of research has documented that the Greek family appears to be a nucle- 
ar family (its members live separately from their families of origin) but they really function as an extended family: they form bonds in which collective values dominate, the children usually choose to live within very close proximity to their parents, they communicate many times daily, they all share their problems and decisions are taken collectively. This type of family has been called "extended urban family" (Georgas, 2000).

Adolescents, on one hand, reject values associated with the patriarchal, rural family (a domineering father and a passive mother) and on the other, they believe in values associated with collectivity. Bonds between the family members, the ancestors and the extended family are very powerful in Greece (Georgas, 1999, 2000). Even while in the process of Europeanization and Globalization, Greece still remains a profoundly religious Christian Orthodox country full of beliefs, traditions, customs and religious feasts (Greeka.com, 2007) that believe and support the institution of family. Besides, divorce rates are lower compared to other countries (OEPEK, 2007). Although there are some research findings related to Greek family and marriage (Georgas, 1999; Hainds, 2000; Maratou-Alipranti, 1995), there has been limited research work done on the marital relationship in a family raising a child with disability.

The purpose of this study is to contribute to the present state of knowledge concerning the impact of raising a child with a severe disability on the marital relationship. This purpose becomes even more compelling for two reasons: a) research on this area on the Greek family is indeed scarce and b) the structure of the Greek family (extended urban family) presents a particularity in the sense that it is neither clearly nuclear nor extended but a mixture of the two. It is therefore interesting to see the possible differences from other structures of families that prevail in the western culture. Specifically, this study examines the impact of the disability on the following areas of the marital relationship: marital satisfaction, representation of the marital relationship, roles and boundaries.

Marital satisfaction has been defined as an attitude concerning the quality of a marital relationship and has been described as a process that is susceptible to change over time. It is considered to be the person's overall evaluation of his or her marriage (Stenberg \& Mojjat, 1997). Moreover, marital satisfaction describes the level of personal happiness and satisfaction an individual feels about his or her marriage. Individuals are usually happy and satisfied when their needs are being met and when the individual's expectations and desires are being satisfied. 
Representation of the marital relationship. The term representation is used to describe the image spouses have of their marital relationship, that is the way they identify it. For instance cooperative versus dissolved or threatened, offering participants the possibility versus the impossibility to share their common interests etc. We assumed that the presence of positive/negative images further indicate that couples experience a satisfactory/unsatisfactory relationship respectively and therefore their representations (concerning their relationship) should correspond to the degree of marital satisfaction as indicated by Marital Happiness Scale (Azrin, Naster \& Jones, 1973).

Marital roles: By definition, a family with a child with disability is faced with more stressors compared to a family with children without disability. This difference is due to the difficulties resulting from the condition of disability. Although it depends on the type of disability (chronic, lethal, etc.) the parental role is more arduous and filled with numerous responsibilities. For some families the care needed takes 24 hours a day, 7 days a week and for many years on end. All this contributes to the family's suffering physically and psychologically (Seligman \& Darling, 2007). Mainly mothers undertake most of the responsibilities in taking care of the child with disability (Ayer \& Alaszewski, 1984). Helpers to the chronic care of the child (but with a less frequent assistance) are fathers and sisters (Carey, 1982). The functional assignment of roles is a characteristic of any satisfactory marital relationship. For the couples raising a child with disability it proves to be even more vital, as its presence allows partners to cope with their stressful parental tasks (Seligman \& Darling, 2007).

Another very important issue we addressed through the interviews was whether the assignment of roles was agreed between marital partners. When roles are imposed, tension increases and the couple's threshold for conflict is low. The presence of imposed versus agreed roles may be considered, therefore, as a factor in the edification of a satisfactory versus unsatisfactory marital relationship.

Boundaries. The concept of boundaries is essential for the understanding of the couple functioning. 'Boundaries' is a concept stemming from that of family structure and they refer to the patterned transactions between members of a system to the exclusion of others. The boundaries of a subsystem are the rules defining who participate (in the subsystem), and how. The function of boundaries is to protect the differentiation of the system (e.g. couple). Every family subsystem has specific functions and makes specific demands on its members. Minu- 
chin, Rosman and Baker (1978) posit that a functional organization within the family must have appropriate boundaries between subsystems: the parental, the siblings, the family unit as a whole, and the individual. Emanating from the boundary concept is a very useful family diagnostic nosology that describes dysfunction: "enmeshed", for a family (or a subsystem) that is overly close; "disengaged", where the family is too distant from one another. Enmeshed boundaries also tend to be diffused and disengaged tend to be rigid. Furthermore, for proper family functioning, the boundaries of subsystems must be clear. They must be defined well enough to allow subsystem members to carry out their functions without undue interference, but they must allow contact between the member of the subsystem and other. All families can be conceived of falling somewhere along a continuum whose poles are the two extreme boundaries and overly rigid boundaries. The spouse subsystem must achieve a boundary that protects it from interference by the demands and need of other systems or subsystem (e.g. children). The adults must have a psychosocial territory of their own -a haven in which they can give each other emotional support. If the boundary around the spouses is inappropriately rigid the system can be stressed by their isolation. But if the spouses maintain loose boundaries, other subgroups, including children and in-laws, may include into their subsystem functioning (Minuchin et. al., 1978).

The risk for a couple raising a child with a severe disability is that they are faced with so many tasks in order to respond to the demands of their child's disability that the boundaries of the couple cannot be maintained (enmeshed) in the sense that the parental role takes up all the 'space' of the marital relationship (e.g. partners have less time for themselves as a couple, parents give priority to the needs of their child at the expense of the marital relationship).

\section{Objectives}

The aim of this study is twofold: i) to examine certain areas of the relationship of the couples with a child with a severe disability and ii) to depict any differences between these couples and the ones with children without disability on the areas assessed. Especially, this research aims to answer the following:

1) What is participants' level of marital happiness?

2) How do participants represent their marital relationship?

3) How are the marital roles assigned?

4) What kind of boundaries characterize the marital relationship? 
It is very important to study and understand participants' representations, roles and boundaries and the impact of these on current marital behaviour. This will help specialists to work with couples aiming to find the appropriate strategies that help families adapt to or cope with the experiences of raising a child with disability. We consider the above questions important because they have not been sufficiently answered by the existing research on the Greek population.

The hypothesis of the study is the following: since there is a lack of formal (governemtal) support networks -specially- in the periphery of Greece (Tsibidaki \& Tsamparli, 2007), Greek families with a child with severe disability turn to other informal sources of support for help such as marital relationship. We consider that these couples function supportively and sufficiently.

\section{Method}

\section{Participants}

Research participants were 60 nuclear families, 30 families with a child with a severe disability and 30 with children without a disability (control group). The total number of research participants was 120 parents. All families were 'nuclear' and intact. Both research groups were matched on the type of family. As we have already mentioned the Greek nuclear family (and the families of the study) functions as an 'urban extended family', that is, their functioning presents characteristics of both nuclear and extended family. It was the first marriage of parents, and all families had children of school age. All were of a middle socioeconomic class. This was based on information derived from parents' occupation and income. The range of families' monthly income was: from $1800 €$ to $3.000 €(\mathrm{M}=2.430 €$ and median $=2.640 €)$ for families with a child with disability and from $1900 €$ to $3.000 €(\mathrm{M}=2.200 €$ and median $=2.450 €$ ) for families of children without a disability. According to the General Secretariat of National Statistical Service of Greece (2009), the middle socioeconomic class of Greeks is between $1800 €-3000 €$. All the fathers were employed (100\%). More mothers of a child with disability (63.33\%) were unemployed compared with mothers of children without a disability (33.33\%). It must be underlined that most mothers (73.68\%) raising a child with a severe disability decided to stop working in order to stay home and take care of the child with disability. Table 1 shows the demographic characteristics of parents related to education and occupation. The educational characteristics of the participants are representative of the Greek 
population (according to General Secretariat of National Statistical Service of Greece, 33.44\% have finished the Lyceum). Moreover, all participants were permanent residents of the island of Rhodes, Greece. The average age of the men was 39 years $(\mathrm{SD}=5.91)$ and of the women was 37 years $(\mathrm{SD}=6.57)$.

Table 1. Participants' demographics of education and work

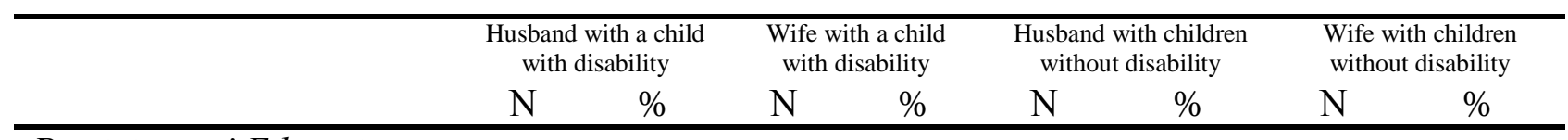

Participants' Education

\begin{tabular}{lcccccccc}
\hline Elementary & 1 & $3.3 \%$ & 5 & $16.7 \%$ & 1 & $3.3 \%$ & 4 & $13.3 \%$ \\
High School & 13 & $43.3 \%$ & 6 & $20 \%$ & 10 & $33.3 \%$ & 7 & $23.3 \%$ \\
Lyceum & 11 & $36.7 \%$ & 10 & $33.3 \%$ & 12 & $40 \%$ & 12 & $40 \%$ \\
College & 1 & $3.3 \%$ & 2 & $6.7 \%$ & 1 & $3.3 \%$ & 2 & $6.7 \%$ \\
University & 4 & $13.3 \%$ & 7 & $23.3 \%$ & 6 & $20 \%$ & 5 & $16.7 \%$ \\
\hline
\end{tabular}

\begin{tabular}{|c|c|c|c|c|c|c|c|c|}
\hline Doctor & 2 & $6.7 \%$ & - & - & 2 & $6.7 \%$ & - & - \\
\hline Lawyer & 1 & $3.3 \%$ & - & - & 1 & $3.3 \%$ & - & - \\
\hline Civil employee & 4 & $13.3 \%$ & 2 & $6.6 \%$ & 6 & $20 \%$ & 3 & $10 \%$ \\
\hline Private employee & 12 & $40 \%$ & 5 & $16.6 \%$ & 11 & $36.7 \%$ & 9 & $30 \%$ \\
\hline Free professional & 10 & $33.3 \%$ & 3 & $10 \%$ & 10 & $33.3 \%$ & 4 & $13.3 \%$ \\
\hline Educator & - & - & 1 & $3.3 \%$ & - & - & 4 & $13.3 \%$ \\
\hline $\begin{array}{l}\text { Unemployed/Household } \\
\text { work }\end{array}$ & - & - & 19 & $63.3 \%$ & - & - & 10 & $33.3 \%$ \\
\hline
\end{tabular}

The total number of children with a severe disability was 30 (15 boys and 15 girls). Age range: 7 to 12 years $(M=8.07, S D=3.02)$. The types of disability were the following: mental retardation (severe) (50\%), cerebral palsy (with the coexistence of moderate mental retardation) (33\%) and multiple disability (motor and language difficulties and severe mental disability) (16.5\%). The common characteristic for all children was the mental retardation (from moderate to severe). All the children of the study were officially diagnosed as presenting, according to the official medical diagnosis, a disability which was estimated as 'severe'. According to the 'New system of classification and evaluation of individuals with disability' in Greece (Institute of Social Protection and Solidarity, 2005), 'severe disability' applies to individuals who face serious restrictions in the fulfillment of their daily activities, and who also need the support of a third person for certain activities. 
The families were randomly selected. The selection took place in two phases: Firstly, families raising a child with disability were randomly selected from archives, catalogues of the Association of Children with Disability of Dodecanese, and secondly, families with children without disability were randomly selected from the directory of the municipality of Rhodes. Registration of families on the above mentioned catalogues is compulsory. The sample of families raising a child with a severe disability was composed using the following criteria: a) all families were intact, b) the age of the child with disability was between 7 and 12 years, c) the child lived with his/her family, d) all the families of the sample were permanent residents of the periphery (island of Rhodes), and e) the child was the only individual in the family who presented with the disability.

The participant families were at first contacted by phone and then visited at their home. Out of the 35 initial calls, only 5 families refused to participate to the research. At the initial visit all parents signed a consent form. At the completion of the research, a summary of the study and a thank-you note for their participation were sent to each family.

\section{Instrments}

Data were collected using the Marital Happiness Scale (Azrin, Naster \& Jones, 1973) and semi-structured interviews.

Marital Happiness Scale (Azrin, Naster \& Jones, 1973. Translated and adapted into Greek by Hainds, 2000). This scale measures the degree of satisfaction that the spouse acquires from the behaviors of his/her spouse in basic areas of couple interaction. It is a 10-item instrument which assesses the level of marital satisfaction in nine different areas of interaction: household responsibilities, the rearing of children, social activities, money, sex, communication, academic progress, personal independence, general happiness. Also, it includes a global assessment of marital happiness with the relationship. The spouse evaluates his/her relationship depending on the satisfaction he/she considers that he/she acquires in every dimension, beginning from 1 (very dissatisfied) to 10 (very satisfied). The final score corresponds to a scale of five gradations (from zero to very satisfied). The psychometrics of the measure for couples with a child with disability indicate alpha coefficients of .89 and .91 for couples with children without disability. 
Semi-structured interviews. Qualitative interviews are a rich means of gathering information from families (Beitin, 2008). Spouses participated in individual, in semi-structured interviews that addressed how they describe and represent their marital relationship, the roles and the boundaries in their marriage. Individual rather than conjoint interviews were conducted to ensure that all participants had ample opportunity to express their individual perspectives and also that there would be no potential for biased responses due to the presence of the partner. Although theorizing in this area focuses on the marital dyad, contemporary studies consider husbands' and wives' attributes separately, rather than dyadically (Helms, Proulx, Maguire-Klute, McHale \& Crouter, 2006). Interviews were conducted by the two researchers using an interview guide that contained questions addressing how spouses describe their marital relationship, their spouses, the assignment of roles and the types of boundaries (See Appendix A). Especially, semi-structured interviews designed to study the following areas:

a) Representation of the marital relationship: This area refers to the way each partner describes his/her marital relationship.

b) The assignment of roles: The assignment of roles constitutes a very important parameter, which contributes to the functioning of the family system. At this level we are interested in whether the assignment of roles is agreed and whether individuals are happy with this agreement.

c) Boundaries: The boundaries are rules that define who and to what extent one participates in a subsystem, what roles one will play in the transactions taking place in a family system. The term 'subsystem' refers to any individual or dyad (e.g. husband and wife) or larger sub-groupings determined by gender, functions, generation etc, within the family. Boundaries may be functional or dysfunctional. Functional boundaries refer to a form of proximity that promotes differentiation and individuality. Dysfunctional boundaries are characterized by over-involvement or disengagement between individuals (within the subsystem or between subsystems).

\section{Procedure}

The initial contact with the couples was made by an employee appointed by the institutions or by the Municipality and then, if accepted to participate in the research there was a telephone contact by the researcher. The research was conducted at the couples' home. At the initial visit parents signed a consent form. After parental consent was obtained, three home visits were arranged (at a time indicated by the family) for the administration of both instruments. All visits took place within a week. The Marital Happiness Scale was administered 
during the first visit and lasted approximately $15^{\prime}$ minutes while the interviews took place at the second and third visit and lasted approximately 1 hour with each participant. The instruments were administered by the same two researchers. Participants were assured that their anonymity would be respected. At the completion of the research, a summary of the study and a thank-you note for their participation were sent to each family.

\section{Data Analysis}

The statistical analysis of the empirical data was performed by the SPSS for Windows v.12. (SPSS Inc, 2003). An independent samples $t$-test criterion for two independent samples was performed on the Marital Happiness Scale data to test the effect of whether or not the family contained a child with disability. All interviews were tape-recorded, transcribed verbatim, and analyzed using the method of analytic inductive approach of content analysis (Berg, 1995). The key phrases were first obtained by frequency counts from the transcribed scripts. Then, these phrases were collected and formulated into several themes such as: representation of marital relationship, assignment of roles and boundaries. Interviews were broken down into spouses (wife - husband) and family (with and without a child with a severe disability). Reliability was established by having an independent researcher (family therapist) who reviewed the scripts again and re-evaluated the themes formulated by the two researchers in order to make sure it was coherent with the scripts and to identify inconsistencies or omissions.

\section{Results}

\section{Marital satisfaction}

According to the quantitative analysis ( $t$-test criterion) of the Marital Happiness Scale there was no statistically significant difference between couples raising children with or without disability, as to how they evaluate their total satisfaction from their marriage [Husbands: $\mathrm{t}$ $(58)=1.246$, n.s \& wives: t $(57)=.703$, n.s]. Participants (in both research groups) grade their marital satisfaction as "very satisfied". For couples with children with disability: Mean=4.49, $\mathrm{SD}=.447$ (husbands) and Mean=4.20, $\mathrm{SD}=.861$ (wives), and for couples with children without disability: Mean=4.32, $\mathrm{SD}=.560$ (husbands) and Mean=4.05, $\mathrm{SD}=.777$ (wives).

\section{Representation of the marital relationship}

The findings of the study concerning the representation of the marital relationship (Table 2) showed that in couples raising a child with a severe disability, the highest percent- 
age of the statements made by the participants referred to a cooperative relationship, although the mother had undertaken most of the responsibilities and obligations concerning the child. For couples with children with disability: $40 \%$ (husbands) \& $46.7 \%$ (wives) and for couples with children without disability: $30 \%$ (husbands) \& 33.3\% (wives). Participants with children with disability say: "Our child has brought us closer and has made us feel united (husband), "My husband understands me more, he supports me. He is a good father, places his children above all and helps me as much as he can. He sometimes feels tired and I can understand this" (wife).

Participants with children with or without disability describe their relationship as lacking sufficient common vital place and time to be shared with their partners. For couples with children with disability: $43.3 \%$ (husbands) \& $36.7 \%$ \& (wives) and for couples with children without disability: $56.7 \%$ (husbands) \& $60 \%$ (wives). A wife with a child with disability says: "With three small children where can I find time for my husband? We sometimes, manage to find a little free time; however, I would have liked more time for us". A wife with children without disability reports: "My husband is always away working. He is overstressed about money, so he doesn't see neither me nor his family enough".

The percentage of participants raising a child with disability who feel that their marital relationship is threatened is higher in comparison to the participants with children without disability. For couples with children with disability: $16.7 \%$ (husbands) \& $20 \%$ (wives) and for couples with children without disability: $3.3 \%$ (husbands) \& $6.7 \%$ (wives). This is a significant finding which indicates that marital dissolution is due to the presence of a child with a severe disability. More specifically, according to two husbands this threat is due to changes introduced in their marital life by the condition of disability. They say: "After the child's birth, all my marital life has changed dramatically" and "Because of this child, my marriage has been destroyed". Still, one might ask: is the 'unhappiness' or 'threat' of the marital relationship due exclusively to the presence of a child with disability or has the child been attributed the role of the scapegoat who is thought to be the cause of all marital unhappiness? Further qualitative research is necessary in order to clarify this finding. The majority of the couples with children with disability feel that the problems in their relationship, either preceded the child's birth or were problems not associated with the condition of disability of the child. Some participants report: "I failed in my marriage. I sometimes wonder: why did I get 
married?" (wife), "She has got her own interests. I believe that we have nothing in common" (husband).

Table 2. Percentages of marital relationship's representations

\begin{tabular}{|c|c|c|c|c|c|c|c|c|}
\hline \multirow{2}{*}{$\begin{array}{l}\text { Representation of marital } \\
\text { relationship }\end{array}$} & \multicolumn{2}{|c|}{$\begin{array}{c}\text { Husband with a } \\
\text { child with disability }\end{array}$} & \multicolumn{2}{|c|}{$\begin{array}{c}\text { Wife with a } \\
\text { child with disability }\end{array}$} & \multicolumn{2}{|c|}{$\begin{array}{l}\text { Husband with children } \\
\text { without disability }\end{array}$} & \multicolumn{2}{|c|}{$\begin{array}{l}\text { Wife with children } \\
\text { without disability }\end{array}$} \\
\hline & $\mathbf{N}$ & $\%$ & $\mathbf{N}$ & $\%$ & $\mathbf{N}$ & $\%$ & $\mathbf{N}$ & $\%$ \\
\hline $\begin{array}{l}\text { Lack of common vital } \\
\text { space and time }\end{array}$ & 13 & $43.3 \%$ & 11 & $36.7 \%$ & 17 & $56.7 \%$ & 18 & $60 \%$ \\
\hline Cooperative relationship & 12 & $40 \%$ & 13 & $46.7 \%$ & 9 & $30 \%$ & 10 & $33.3 \%$ \\
\hline $\begin{array}{l}\text { Dissolve of marital rela- } \\
\text { tionship }\end{array}$ & 5 & $16.7 \%$ & 6 & $20 \%$ & 1 & $3.3 \%$ & 2 & $6.7 \%$ \\
\hline
\end{tabular}

\section{Assignment of roles}

According to the findings of the study, participants report that role assignment is agreed upon (Table 3). In participants raising a child with disability the assignment of roles is at the disadvantage of the mother. For couples with children with disability: 60\% (husbands) \& $60 \%$ (wives) and for couples with children without disability: $43.3 \%$ (husbands) \& $43.3 \%$ (wives). The wife has undertaken the greatest burden of responsibilities and obligations concerning the child with disability. Wives state the following: "Unfortunately, everything has to be done by me, work, housework, children. Men are....you know, more easy-going, do not bother very much with the housework", (wife with a child with disability), "My husband works all day long and is away, he does not help in any way, and everything has to be done by me" (wife with children without disability). This hyperfunction of the mothers' role is recognized by their husbands. Husbands say: "Of course, my wife gets more tired, I wish I could help her more but I just can't find the time" (husband with a child with disability), "My wife is the captain of our house, I do not know how she manages all, I admire her (husband with children without disability).

Other participants report that they have equal role assignment, with higher percentage being recorded in participants with children without disability. For couples with children with disability: $36.7 \%$ (husbands) \& $36.7 \%$ (wives) and for couples with children without disability: $56.7 \%$ (husbands) \& 56.7\% (wives). They say for example: "I believe that we have shared housework in such a way that we have time" (husband with a child with disability), "Luckily, I have great help from my husband" (wife with children without disability). 
A very important finding is that for all the families raising a child with a severe disability (100\%) everything functions and is organized around the child. A husband states: "Our life and daily schedule depends on our child (mentioning the name of the child with disability)". The risk for a couple with a child with disability is that they are faced with so many tasks in order to respond to the demands of their child's disability that the boundaries of the couple cannot be maintained (enmeshed) since the parental role takes up all the 'space' of the marital relationship. Therefore the parental role functions at the expense of the marital relationship (e.g. partners have less time for themselves, their social life as a couple etc).

\section{Table 3. Percentages of roles' assignment}

\begin{tabular}{|c|c|c|c|c|c|c|c|c|}
\hline \multirow[t]{2}{*}{ Roles' assignment } & \multicolumn{2}{|c|}{$\begin{array}{c}\text { Husband with a } \\
\text { child with disability }\end{array}$} & \multicolumn{2}{|c|}{$\begin{array}{l}\text { Wife with a } \\
\text { child with disability }\end{array}$} & \multicolumn{2}{|c|}{$\begin{array}{l}\text { Husband with children } \\
\text { without disability }\end{array}$} & \multicolumn{2}{|c|}{$\begin{array}{l}\text { Wife with children } \\
\text { without disability }\end{array}$} \\
\hline & $\mathbf{N}$ & $\%$ & $\mathbf{N}$ & $\%$ & $\mathbf{N}$ & $\%$ & $\mathbf{N}$ & $\%$ \\
\hline $\begin{array}{l}\text { Unequal assignment of } \\
\text { roles at the disadvantage } \\
\text { of the mother }\end{array}$ & 18 & $60 \%$ & 18 & $60 \%$ & 13 & $43.3 \%$ & 13 & $43.3 \%$ \\
\hline $\begin{array}{l}\text { Equal assignment of roles } \\
\text { Unequal assignment of }\end{array}$ & 11 & $36.7 \%$ & 11 & $36.7 \%$ & 17 & $56.7 \%$ & 17 & $56.7 \%$ \\
\hline $\begin{array}{l}\text { roles at the disadvantage } \\
\text { of the father }\end{array}$ & 1 & $3.3 \%$ & 1 & $3.3 \%$ & - & - & - & - \\
\hline
\end{tabular}

\section{Boundaries}

An interesting finding, as far as boundaries are concerned (Table 4), is that participants from both groups describe their relationship with their partner as disengaged and rigid while their relationship to the child with disability is enmeshed and diffuse. For couples with children with a severe disability: $16.7 \%$ (husbands) \& $26.7 \%$ (wives) and for couples with children without disability: $13.3 \%$ (husbands) \& 20\% (wives) $(23.3 \% \& 28.3 \%$ ). For both groups, participants (especially wives) seem to maintain an enmeshed relationship with the child and a disengaged and rigid with partner. For couples with children with disability: $16.67 \%$ (husbands) \& $26.7 \%$ (wives) and for couples with children without disability: $13.3 \%$ (husbands) \& $20 \%$ (wives). That is, they are overly close to the child; they seem to concentrate on the child's needs, while they seem to minimize the importance of their marital relationship. They describe the situation as follows: "I believe that somehow our feelings have... somehow shrunk, especially me. It is as if I do not wish for anything or anybody; I simply care about myself and my daughter" (wife with children without disability). 
Still, the overemphasis on the parental role and the minimization of the marital relationship don't seem to be experienced as a source of marital unsatisfaction for the majority of the couples. Boundaries seem to be clear for both groups of families. For couples with children with disability: $60 \%$ (husbands) \& 50\% (wives) and for couples with children without disability: 53.3\% (husbands) \& 56.7\% (wives). They express this with the following: "It is quite clear to me what each of us has to do for our family," "I feel that rules and principles are kept as they should in our marriage. We have agreed in advance how things will work in our family" (wife with children without disability).

\section{Table 4. Percentages of boundaries}

\begin{tabular}{lcccccccc}
\hline Boundaries & $\begin{array}{c}\text { Hubband with a } \\
\text { child with disability }\end{array}$ & \multicolumn{2}{c}{$\begin{array}{c}\text { Wife with a } \\
\text { child with disability }\end{array}$} & $\begin{array}{c}\text { Husband with children } \\
\text { without disability }\end{array}$ & \multicolumn{2}{c}{$\begin{array}{c}\text { Wife with children } \\
\text { without disability }\end{array}$} \\
& $\mathbf{N}$ & $\mathbf{\%}$ & $\mathbf{N}$ & $\mathbf{\%}$ & $\mathbf{N}$ & $\mathbf{\%}$ & $\mathbf{N}$ & $\mathbf{\%}$ \\
\hline Clear & 18 & $60 \%$ & 15 & $50 \%$ & 16 & $53.3 \%$ & 17 & $56.7 \%$ \\
Rigid/Disengaged & 7 & $23.3 \%$ & 7 & $23.3 \%$ & 10 & $33.3 \%$ & 7 & $23.3 \%$ \\
Diffuse/Enmeshed & 5 & $16.7 \%$ & 8 & $26.7 \%$ & 4 & $13.3 \%$ & 6 & $20 \%$ \\
\hline
\end{tabular}

\section{Discussion}

According to the findings concerning our research question: "What are the participants' levels of marital satisfaction?", there was no statistically significant difference in the grading of the Marital Happiness Scale between the participants. The partners (in both research groups) grade their marital relationship as "very satisfied". This finding is consistent with those of other studies which suggest that there is no difference in marital relationship in families raising children with disability in comparison with families of children without disability (Floyd \& Zmich, 1991; Holmbeck et. al., 1997; Patterson, 1991). On the contrary, this finding is not consistent to those according to which families with a mentally retarded child (Friedrich \& Friedich, 1981), as well as couples with children with hearing difficulties experience quite low marital satisfaction (Konstantareas \& Lambropoulou, 1995).

The above finding equally indicates that the presence of a child with disability does not necessarily inflict a negative influence on the marital relationship. This finding is consistent with those of other studies (Dale, 1996; Seligman \& Darling, 2007; Woolfson, 1991) but it is not consistent with those findings that support the negative influence of the child with disability on the marital relationship (Pahl \& Quine, 1985). Furthermore, in research literature 
(Sloper \& Turner, 1993; Dale, 1996) marital satisfaction is regarded to be one of the "Protective factors" which provide resilience to stressful events and increase coping ability of the family. It also comes to support the statement that families are often resilient (Peralta \& Arellano, 2010).

In the case of couples who feel that their marital relationship is so unsatisfactory that they wish to divorce, a small percentage (Mean=18.3\%) reported that they felt that this was due to problems caused by the disability of the child. The majority of the participants stated that problems in their marriage were present either prior to the birth of their child or that the condition of disability was not related to these problems. This result contributes to other studies which support that there is no increase in divorces in families of children with disability compared to families of children without disability (Dale, 1996; Seligman \& Darling, 2007).

Some participants with a child with disability (Mean= $43.3 \%)$ seem to have a cooperative marital relationship. This finding is consistent with those of other studies (Schwab, 1989). In couples raising children without disability this percentage is lower (Mean=31.7\%). This cooperation concerns mainly tasks associated with the condition of disability. Therefore the existence of a child with disability brings partners together but mainly in their parental role. A role that seems to function as the 'organizer' of the life of the couple in the sense that life is organized around the needs of the child with a severe disability. These families are therefore 'child-centered'. This finding confirms those of other studies (Antzakli-Xanthopoulou, 2003; Dale, 1996; Seligman \& Darling, 2007). Interestingly enough, in both research groups partners do not seem to overemphasize the parental role at the expense of the marital one. This is, therefore, not due to the existence of a child with a severe disability only. One possible interpretation is that the Greek family is mainly 'child centered' (Georgas, 1999). This is possibly due on one hand to its collective values and on the other to the fact that the Greek state does not support the family (lack of all kinds of structures who could provide services).

That is, after partners become parents they seem to give priority to their parental role. This applies more to mothers than fathers. It is a socially accepted behaviour probably associated with the fact that in Greece networks of support are insufficient (in number and function) and therefore unable to support the Greek family (Tsibidaki \& Tsamparli, 2007). Therefore, the family alone has to undertake and respond to their children's needs. 
According to the findings of the study concerning our research question: "How are the marital roles assigned?", the assignment of roles, in both research groups, is not imposed but agreed upon by the spouses. An interesting finding is that participants with children with disability organize their life around the needs of the child with disability and of those of their siblings. Therefore, on one hand the disability seems to function as an organizer of the family's functioning and on the other it suggests that there is an 'agreed' upon coping strategy of the couple in order to face the high demands of care imposed by the condition of the disability.

In families raising children with a severe disability, the mother carries the greatest burden of responsibilities and obligations (60\%). This finding is consistent with those of other studies on couples raising a child with disability in Greek families (Antzakli-Xanthopoulou, 2003), as well as couples of other nationalities (Lamb, 1986; Schilling, Schinke \& Kirkham, 1985). This overfunctioning of the mother, which is acknowledged by their husbands, was also found in families with children without disability. The finding that mothers perform more tasks than fathers and undertake mainly roles of care for the family is consistent with other research findings in Greek families (Maratou-Alipranti, 1995). A main finding of the study is that mothers undertake a multiplicity of roles. This is due to the fact that in the Greek family women are expected to undertake more caretaking roles than men in the household (Georgas, 1999). There is a contradiction in this finding that leads to the following question: how can participants feel that the relationship is cooperative since wives undertake most of the responsibility concerning the child with disability? This could be attributed to the fact that although Greek women have new roles (e.g. they work), they still maintain some traditional ones like commitig themselves to the household and the children. Therefore, they undertake most of the responsibility of the child because they regard this part of their role. This finding is consistent to the findings suggesting that mothers take up a multiplicity of family roles (Lusting \& Akey, 1999).

Besides, mothers of children with disability state that although they find that their role is tiring, they also state that, when the situation is such (e.g., new needs due to inevitable medical care, an emergency) and more help is needed, their husbands respond positively by undertaking more roles and become "real helpers." Therefore in the families raising a child with a severe disability there is a complementarity of roles which seems to play a decisive role in the functioning of the couples in order to face the demands of care imposed by the condition of disability. At the same time, families raising a child with disability change with the passing of 
time and especially when the child presents new medical needs and new demands. The roles of the families' members in every subsystem (parental, spousal, sibling), as well as among subsystems, should be complementary. When one relationship changes, the other one changes too, in order to fulfill the aims of the family (Goldenberg \& Goldenberg, 1996).

According to the findings of the study concerning the research questions: "What kind of boundaries characterize the marital relationship?" and "How do participants represent their marital relationship?", participants raising children with or without disability do not present any significant difference between them as regards boundaries. Most of the participants, according to the means ( $55 \%$ \& 55\%), show sufficient cohesion, corresponding to the healthy zone of family functioning. This finding confirms those of other studies (McCubbin, Thompson \& McCubbin 1996. Lusting \& Akey, 1999), which suggest that clear boundaries help the development of the child with disability (McCubbin \& Huang, 1989).

Some participants raising a child with a severe disability seem to maintain a disengaged relationship; that is, they do not share common areas of experience (e.g. spend enough time together, have common leisure time and engage in activities without the child). The parental role has taken up most of the private space of the couple. More specifically, $35 \%$ of couples with a child with disability feel that they do not spend enough time with their partner and for couples with children without disability this percentage is $56.66 \%$. It seems that the boundaries of the participants with children with disability are diffused: the parental role dominates in the family. This hypertrophy of the parental role takes place at the expense of the marital relationship. There is more parental closeness but less couple closeness. However, the majority of participants report satisfied with their marriage although they give priority to their child with disability. It seems that the couple changes its boundaries to respond to the demands of the condition of disability. They function as an interfamilial network of support and as it has often been mentioned (Havens, 2009) networks of support are most important for a family raising a child with disability. Quite interesting is the finding that a higher percentage of the partners in couples with children without disability refer to the lack of common vital space and time with their partner and they report that this is due to excessive time devoted to work as well as to the demands of the fast pace of life. In conclusion partners of both groups share a disengaged marital relationship. For the families raising a child with disability this is due to the existence of the child. For the families raising children without disability this is due 
: a) to the fact that the Greek family is child-centered and the parental role is given excessive emphasis, and b) participants devote a lot of time at work and less to their life as a couple.

\section{Limitations}

There is a number of limitations in the present research, which should be noted. First, the sample is situated in the periphery of Greece. It would be most useful to carry out a comparative study between the sample of the study and others situated in the capital in order to see other possible ways of relating in couples. Second, the study's sample inclusion criteria indicated that only one child in the family was diagnosed with severe disability; results may vary if more than one member has disability. Third, a comparison between different degrees and categories of disability would be most desirable. Finally, the administration of alternatives measurements (quantitative ones) for data collection could be used.

\section{Conclusions and Implications for Practice}

According to the findings of the present study there are more similarities than differences between couples raising children with or without disability regarding marital satisfaction, role assignment, representation of the marital relationship and boundaries. In both research groups the parental role dominates in the family. This hypertrophy of the parental role takes place at the expense of the marital relationship. This finding is probably associated with the fact that the Greek family is child-centered.

One difference between the two groups is that for families raising a child with disability the overfunction of the parental role is associated mainly with the existence of the child with disability, while for families with children without disability it is associated with the way they conceive their role and also with the demands imposed upon them by work. Another difference is that a higher percentage of families raising a child with disability experience their marital relationship as unsatisfactory and their marriage as dissolving. The implications of this finding is that when working with families raising children with disability we should not construe the differences in the functions of such families as dysfunctions when compared to others, but as ways of adapting to the condition of disability. Furthermore, such differences in functioning do not mean that the couple with a child with disability is unsatisfied.

Therefore, each partner should be offered the opportunity to independently verbalize his/her views, emotions and representations of his/her family, so that individual concerns can 
be more accurately assessed. Specialists (psychologists, special educators, social workers, family therapists) need to deliberately support family strengths, including a shared view of each family member's emotions and representations. Where potential or real problems and practices are identified, specialists can intervene with appropriate family-focused assessment and counselling and refer families for more in-dept family intervention or therapy when indicated. Finally, future research efforts should be directed to the area of marital relationship aiming family practitioners, clinicians and educators to include both spouses in the evaluation and treatment of the child with disability and to incorporate families into child's care and education. Finally, we consider it would be useful to adapt the suggestion made by Irving Dickman and Sol Gordon in their book One Miracle at a Time (1985 as cited in Havens 2009) "it is not the child's disability that handicaps and disintegrates families; it is the way they react to it and to each other".

\section{References}

Havens, C.A. (2009). Becoming a resilient family: Child disability and the family system. Bloominghton, IN: National Center on Accessibility, Indiana University. Retrieved February 28, 2009, from: www.ncanline.org.

Antzakli-Xanthopouloy, E. (2003). Family with a disabled child. Unpublished Doctoral Thesis, University of Athens. [in Greek].

Ayer, S., \& Alaszewski, A. (1984). Community care and the mentally handicapped: Services for mothers and their mentally handicapped children. London: Croom Helm.

Azrin, N., Naster, B., \& Jones, R. (1973). Reciprocity counseling: A rapid learning-based procedure for marital counseling. Behavior Research and Therapy, 11, 365-382.

Beitin, B.K. (2008). Qualitative research in marriage and family therapy: Who is in the interview? Professional Psychology and Family Therapy, 30, 48-58.

Berg, B.L. (1995). Qualitative research methods for social sciences. Boston: Allyn \& Bacon.

Calias, M. (1989). Counselling work with parents of disabled children. In G. Tsiantis \& S. Manolopoulos (Eds.), Current Issues in Child Psychiatry (pp. 219-249). Athens: Kastaniotis. [in Greek].

Carey, G. (1982). Community care - care by whom? Mentally handicapped children living at home. Public Health, 96, 269-278.

Dale, N. (1996). Working with families of children with special needs. London: Routledge.

Friedrich, W.N., \& Friedrich, W.L. (1981). Psychological assets of parents of handicapped and non-handicapped children. American Journal of Mental Deficiency, 85, 551-553. 
Florian, V., \& Findler, L. (2001). Mental health and marital adaptation among mothers of children with cerebral palsy. American Journal of Orthopsychiatry, 71, 358-367.

Floyd, F., \& Zmich, D. (1991). Marriage and the parenting partnership: Perceptions and interactions of parents with mentally retarded and typically developing children. Child Development, $62,1434-1448$.

Gabel, H., McDowell, J., \& Coreto, M.C. (1983). Family adaptation to the handicapped infant. In S.G. Garwood \& R.R. Fewell (Eds.), Educating handicapped infants (pp. 455493). Rockville, MD: Aspen.

Georgas J (2000) Psychodynamic of family in Greece: Similarities and differences with other countries. In A. Kalatzi-Azizi \& I. Besevegis (Eds.), Issues of training and sensitization of workers in centers for mental health of children and adolescents (pp. 231-251). Athens: Greek Letters. [in Greek].

Georgas, J. (1999). Psychological consequences of family structure and function: A crosscultural approach. Psicologia Italiana, 17, 38-42.

Goldenbreg, I., \& Goldenberg, H. (1996). Family therapy. An overview (4 ${ }^{\text {th }}$ ed.). USA: Brooks/Cole Publishing

Hainds, E. (2000). Marital therapy. Athens: Greek Letters. [in Greek].

Hartley, S., Barker, E., Seltzer, M., Greenberg, J., \& Floyd, F. (2011). Marital satisfaction and parenting experiences of mothers and fathers of adolescents and adults with autism. American Association of Intellectual and Developmental Disabilities, 116, 81-95.

Havens, A. (2005). Becoming a resilient family: Child disability and the family system, Access Today, Spring 2005 - Special Volume, Issue 17. Retrieved May 5, 2008, from http://www.indiana.edu/ nca/monographs/17family.shtml.

Helms, H. Proulx, C., Maguire-Klute, M., McHale, S., \& Crouter, A. (2006). Spouses' gender-typed attributes and their links with marital quality: A pattern analytic approach. Journal of Social and Personal Relationships, 23(6), 843-864.

Holmbeck, G., Gorey-Ferguson, L., Hudson, T., Seefeldt, T., Shapera, W., Turner, T., et. al. (1997). Maternal, paternal, and marital functioning in families of preadolescents with spina bifida. Journal of Pediatric Psychology, 22, 167-181.

Institute of Social Protection and Solidarity (2005). New system of classification and evaluation of individuals with disabilities. Athens. [in Greek].

Kamp-Dush, C., \& Amoto, P. (2005). Consequences of relationship status and quality for subjective well-being. Journal of Social and Personal Relationships, 22(5), 607-627. 
Kersh, J., Hadvat, T., Hauser-Cram, P., \& Warfield, E. (2006). The contribution of marital quality to the well-being of parents of children with disabilities. Journal of Intellectual Disability Research, 50(12), 883-893.

Khamis, V. (2007). Psychological distress among parents of children with mental retardation in the United Arab Emirates. Social Science \& Medicine, 64, 850-857.

Knafl, K., \& Gilliss, C. (2002). Families and chronic illness: A synthesis of current research. Journal of Family Nursing, 8(3), 178-198.

Konstantareas, M., \& Lambropoulou, V. (1995). Stress in Greek mothers with deaf children: Effects of child characteristics, family resourced and cognitive set. American Annals of the Deaf, 140(3), 264-270.

Lamb, M. (1986). The changing roles of fathers. In M. Lamb (Ed.), The father's role: Applied perspectives (pp. 3-27). New York: Wiley.

Lustig, D., \& Akey, T. (1999). Adaptation in families with adult children with mental retardation: Impact of family strengths and appraisal. Education and Training in Mental Retardation and Developmental Disabilities, 34(3), 260-270.

Maratou-Alipranti, L. (1995). Family in Athens. Family patters and marital practices. Athens: E.K.K.E. [in Greek].

McCubbin, H., Thompson, A., \& McCubbin, M. (1996). Family assessment: Resiliency, coping and adaptation - inventories for research and practice. Madison, WI: University of Wisconsin System.

McCubbin, M., \& Huang, S. (1989). Family strengths in the care of handicapped children: Targets for intervention. Family Relations, 38, 436-443.

Minuchin, S., Rosman, B., \& Baker, L. (1978). Psychosomatic families. Cambridge, MA: Harvard University Press.

NationMaster (2003). Encyclopedia: Peripheries of Greece. Retrieved January 22, 2009, from: http://www.nationmaster.com/encyclopedia/Peripheries-of-Greece.

OEPEK (2007). The relation of family and culture environment to the school progress of the child. Ahtens: OEPEK. [In Greek].

Pahl, J., \& Quine, L. (1985). Families with mentally handicapped children: A study of stress and of services response. Canterbury: Health Services Research Unit, University of Kent.

Patterson, J. (1991). A family systems perspective for working with youth with disability. Paediatrician, 18, 129-141. 
Peralta, F., \& Arellano, A. (2010). Family and disability: A theoretical perspective on the family-centered approach for promoting self-determination. Electronic Journal of Research in Educational Psychology, 8(3), 1339-1362. Retrieved September 2, 2012, from: http://www.investigacion-psicopedagogica.org/revista/new/english/LeerArticulo. php.

Rolland, J. (1989). Chronic illness and the family life cycle. In B.Carter \& M. McGoldrick (Eds), The changing family life cycle (pp. 433-454, $2^{\text {nd }}$ ed.). London: Allyn and Bacon.

Schilling, R., Schinke, S., \& Kirkham, M. (1985). Coping with a handicapped child: Differences between mothers and fathers. Social Science Medicine, 21, 857-863.

Schwab, L.O. (1989). Strengths of families having a member with a disability. Journal of the Multihandicapped Person, 2, 105-117.

Seligman, M., \& Darling, B. (2007). Ordinary families, special children ( $3^{\text {rd }}$ ed.). New York: The Guilford Press.

Sloper, P., \& Turner, S. (1993). Risk and resistance factors in the adaptation of parents of children with severe physical disability. Journal of Child Psychology and Psychiatry, 34, 167-188.

SPSS Inc (2003) SPSS for Windows v12.0. Chicago, Illinois: SPSS, Inc.

Sternberg, R., \& Hojjat, M. (1997) (Eds). Satisfaction in close relationships. New York: Guilford Publications.

Stevens, N., \& Westerhof, G. (2006). Partners and others: Social provisions and loneliness among married Dutch men and women in the second half of life. Journal of Social and Personal Relationships, 23(6), 921-941.

Tsibidaki, A., \& Tsamparli, A. (2007). Support networks for the Greek family with preschool or school age disabled children. Electronic Journal of Research in Educational Psychology, 5(2), 283-306. Retrieved September 17, 2007 from: http://www.investigacionpsicopedagogica.org/revista/new/english/LeerArticulo.php.

Williams, K. (2003). Has the future of marriage arrived? A contemporary examination of gender, marriage, and psychological well-being. Journal of Health \& Social Behavior, $44,470-487$.

Woolfson, R. (1991). Children with special needs. A guide for parents and carers. London: Faber and Faber. 


\section{Appendix 1. Semi-structured interview protocol}

(Note: As the interviews were semi-structured, interview questions varied depending on individual responses)

Main research question: How would you describe your marital life?

Part I: Demographic questions related to:

- Age, gender, educational level, professional and financial status

- Duration of marriage, number of children

Part II: Introduction questions to warm up the conversation

- How are things in your family now?

Part III: Exploring the participants' representations of their marital relationship

- How would you describe your life with your partner?

- Would you say that there are positive and negative aspects in your relationship with your partner? If yes, which are they?

Part IV: Exploring the marital roles assignment

- Is it clear to you how things in the family should be done and by whom they should be carried out?

- How do you feel with what you have to do?

- Would you like to see a change in the way responsibilities and chores are shared?

- How do you feel about the way tasks are assigned?

Part V: Exploring the boundaries

- Do you share any activities and spend free time with your partner?

- How do you feel about the rules in your marital relationship?

- Do you think that rules are kept or not? How do you feel about that?

Part VI: Ending the interview

Our questions are up to here; do you have anything else you would like to add about your marriage or your partner? Or anything related we forgot to ask, but you would like to talk about? 